\title{
OPTIMIZATION OF PUBLIC INCOME AND EXPENDITURE IN THE SOCIAL INTEREST AND THE DEVELOPMENT OF LOCAL COMPANIES IN FRENCH LAW
}

\author{
MICHAE MARIAŃSKII
}

\begin{abstract}
This contribution deals with the issue of the optimization of public income and expenditure in the social interest. As the process mentioned above can be done not only on the central but also on the local level, the paper is going to analyze how the legal forms that can be created by local government units in France can realize the social interests of the given community. The main aim of the contribution is to confirm or disprove the hypothesis that the concept of public and social interest, also at the local level, needs to be ensured by a specially created legal forms. These legal forms are very often acting on the market on the basis of the specific rules that are sometimes excluding the free market economy in the given areas. The description of such legal forms, that are very often inspired by the construction of the joint-stock company or limited liability company, can be useful not only for Polish legislator but also for the other East and Centre European Union Countries in the process of the development of their public and local finances regulations. The comparative perspective of the paper may also show the differences in the concept of the social and public interest that are in the French and Polish legal system.
\end{abstract}

\section{Keywords}

Public finance; French law; local government units; local companies

\section{JEL Classification: D63, E72, E79}

1 Doctor of legal sciences, Department of Financial Law, the lecturer at Faculty of Law and Administration UWM in Olsztyn, Poland. Graduated at Faculté de droit - Université d'Auvergne (Clermont-Ferrand (France), The Author specializes in the law of the financial market, international private law and comparative law with a specialization in French law. He is the author of more than 40 reviewed articles in different journals and books. He is a member of Association Henri Capitant des Amis de la Culture Juridique Française and an attorney at law being a member of Regional Bar Associations in Olsztyn. Contact email: michal.marianski@ uwm.edu.pl. 


\section{Introduction}

Public interest (fr. intérêt public), in French law, is more often referred to as social interest (intérêt social) and is very often used as justification for numerous administrative and financial legal regulations. In addition, the public interest is also visible in the case law of the Supreme Administrative Court (fr. Conseil d'Etat) and the Supreme Constitutional Court (fr. Conseil constitutionnel) and it is used often enough to justify partial disregard for certain economic freedoms or public rights in a given area.

Social interest is also one of the reasons for introducing legislation locally in order to make it more possible for local governments in France - known there as territorial units - to optimize public income and expenditure. It should be highlighted that social interest is an extremely general concept which is explained and interpreted at every occasion, not only in terms of the principles followed by a locality but mostly in terms of the circumstances of a specific case. In European law, social interest is considered to be a general clause, thus it is essentially defined and explained through the case law and legal studies (Broch, 2014: 179). Therefore, this concept may not only vary in definition when it comes to an individual branch of law, but also become a certain variant of itself in a particular field of research, e.g. public finance law, depending on the laws or regulations where it is used and on the situation to which it should be applied (Cornu, 2005: 496).

Both in Polish law and in French law, public (social) interest is one of the most important general clauses construed as imprecise terms whose purpose is to ensure flexibility in applying legal regulations. That interest should apply to the entire society or at least to a part of it - a unit, for instance. Thus, further in this paper, the application of the concept of social interest is analyzed in order to introduce certain changes locally when it comes to the status of companies through which French municipalities and communes may perform public tasks. It is worth emphasizing that the concept of social interest is somehow double-sided since it is applied not only to delineate the boundaries of permissible interference of the state in social and economic affairs as well as in civil rights liberties but also to determine the limits of the conduct of organizations in dealings with the state.

That concept discussed very often in Polish law and French law, is defined in the case law. Thus, for instance, one may find in the legislation of the French Conseil d'Etat the extension of the scope of the social interest clause from public entities to private entities (Conseil d'Etat Court: CE Ass. 5.05.1976) and the confirmation that it is possible to restrict or disregard certain freedoms and liberties, including those related to the freedom of establishment, if only it is in the said social interest (Conseil d'Etat Court: CE Ass. 28.05.1971). According to the Polish legislation, 
Optimization of Public Income and Expenditure in the Social Interest...

the public interest is a general clause which should be adequately interpreted on a case-by-case basis. Requirements of the public interest have to be defined in a specific case and have to be individualized based on the actual and legal status of the case (Supreme Administrative Court no.: II FSK 71/13). In addition, as noted by the Polish Administrative Court, in order for the tax authority to identify whether an action is in the public interest, it has to consider it from two standpoints: a general standpoint and an individual standpoint. The authority is supposed to establish what is more advantageous from the perspective of public interest, also taking into account other directives and interpretation clauses common to the entire society (Supreme Administrative Court no.: II FSK 4126/14).

\section{Evolution of Structure of Local Units in France}

In order to present how the structure of territorial units in France has evolved, it is worth emphasizing that, in contrast to the distinctive and uniform definition of local government in Polish law, there are three different (though identical in terms of meaning) definitions in French law. Specifically, those definitions refer to the concept of local communities (fr. collectivités locales), to the concept of administration division (fr. administration teritoriale), and to the most frequently applied concept of decentralized administration (fr. administration décentralisée). Territorial units in France today were established and organized under the Act of 2 March 1982 on Freedoms and Liberties of Municipalities, Communes, Departments, and Regions. That Act identified three key territorial units in France as municipalities, communes (fr. communes), departments (fr. départements), and regions (fr. régions) (Sitek, 2011: 61). Moreover, in accordance with the Territorial Units Code (fr. Code général des collectivités territoriales), a territorial unit is defined as a decentralized unit with legal personality and specific competencies granted by the state authorities, acting under the administrative authority by issuing decisions reflecting the approval of actions undertaken by bodies functioning within such a unit (Monjal, 2013: 449).

In addition, it is also worth highlighting that in 2015 the competences of already existing so-called special collectivities (fr. collectivité à statut particulier) ${ }^{2}$, overseas units (fr. collectivité d'outre-mer) ${ }^{3}$, and uninhabited territories (fr. territoires inhabités ${ }^{4}$ were regulated. In France, the most important role, also when it comes to the implementation and application of the concept of social interest as part of budget income and expenditure optimization through local companies, is played by municipalities and communes (fr. communes). Municipalities and communes

\footnotetext{
As e.g. Corsica.

As e.g. Mayotte, French Polynesia, and New Caledonia.

As e.g. southern and Antarctic territories and Crozet Islands.
} 
have a uniform legal status in France, though they are very diverse in terms of area and population. Based on the information retrieved from the French statistical office (INSEE) , as at 31 October 2017 in France, there are 35,414 municipalities and communes (including 129 overseas municipalities and communes). It has to be emphasized that since 2015 the number of French municipalities and communes has been gradually decreasing; this trend follows the reform of French units. For example, in 2016 there were 493 operations of mergers of municipalities and communes reported (fr. opérations de fusion d'intercommunalités) which in the past occurred extremely rarely, a few mergers per year at most. The foregoing results from the very high fragmentation of municipalities and communes in France, since as many as $2 / 3$ of those units have an area smaller than 1500 ha and only $2 \%$ of them have an area of 5500ha (Donier, 2014: 190).

The aforementioned process aimed at reducing the number of individual types of units in France is most visible in the structure of regions. Namely, since 1 January 2016, the number of regions has decreased from 27 to 18 (Orcier, 2015: 143). Such a procedure, expected to improve local financial management, is all the more interesting from the perspective of Polish law, as in Poland it is more often considered to increase the number of voivodships - equivalents of regions in France. Thus, ultimately, from among 18 French regions, only 13 will be continental regions of France and the remaining five of them will be so-called overseas regions (fr. régions d'outre-mer) (Lasserre, 2016: 8).

It is also worth noting that along with the evolution of the structure of territorial units in France, there have also evolved legal means that those territorial units can use to optimize public income and expenditure in the social interest. Namely, for a very long time those means, developed under the regulations generally applicable to public companies, were subject to free or only slightly restricted competition in the market. As a result of changes also introduced in the EU laws, the French lawmakers significantly increased the legal possibilities to establish companies locally in order to implement important public tasks. Therefore, the provisions of the French Commercial Code (fr. Code de commerce) were an impulse for the development of numerous interesting legal means which are non-existent in the laws of Poland or of other Central and Eastern European countries.

\section{Local Companies Operating on Market Conditions}

Originally, French territorial units for a long time were based on two, typical French legal concepts of public undertakings which include public establishments 
Optimization of Public Income and Expenditure in the Social Interest...

(fr. établissement public) and public enterprises (fr. entreprise public). The notion of public service and public interest appeared in French law through the case law of the above-mentioned Supreme Administrative Court - Conseil d'Etat. It is particularly noteworthy that the meaning and extent of the concept of public service was explained by the French judiciary in the Blanco judgement dated 8 February 1873, and in the Pelltier judgement dated 30 July 1873 in which the responsibilities of the public authorities were defined when they do not fulfil their obligations properly the obligations which very often are aimed at acting in the widely understood social interest (Chapuis, 1998: 12).

It was precisely due to the need to perform many tasks in the general social interest discussed here that people very quickly noted there was a need to define new organizational and legal means based on the means and measures already existing in the Commercial Code. Therefore, it was decided to create a special category of local companies whose structure was based on the provisions of the French Commercial Code regarding public companies. It was noted that modifying the structure of a public company may help French territorial units create quasi-public entities which more easily and flexibly could perform public tasks. However, what is important is the fact that such entities would generally be subject to free competition which was supposed to materially affect the quality and transparency of their operations.

An example of a legal means developed to satisfy the needs of local entities, and especially of municipalities, are local companies established as semi-public companies (fr. société d'économie mixte locale). The necessity to satisfy public needs of the local population, but only if it was not possible through a private initiative, is a prerequisite for using that modified form of a public company. Thus, a local company should be brought to life only if its activities ensure not only the optimization of public income and expenditure but also allow for the satisfaction of the overall needs of a locality, regardless of whether its activities risk permanently generating losses. Therefore, in reference to Polish law, the aforementioned legal form of a local and simultaneously public company may be compared to a municipal company in Poland, bearing in mind that it is similar to its French equivalent only to a certain extent (Byjoch, Klimek, 2015: 12).

The first complete law allowing the establishment of local public undertakings under the provisions regarding public companies was introduced in 1983. The core idea of the French lawmakers was to create such legal persons where the majority shareholders could be territorial units. Due to basing their structure on the provisions of the Commercial Code regarding public companies, local companies have capital divided into shares owned by various shareholders whose liability is limited to the number of their contributions. A major constraint is the fact that the number of shareholders of such a company may not be smaller than seven entities, which 
is supposed to encourage the establishment of such legal entities in collaboration among a few municipalities and/or communes (fr. coopération intercommunale). In practice, such companies are formed very frequently not only in collaboration with public law entities, but also in collaboration with one or, very often, more private entities. Because of the foregoing, when comparing such companies to entities provided for in Polish law, one may find many similarities to the institution of a public-private partnership (Michalak, 2014: 12) It is difficult to find such a comparison in the French doctrine since there is a prevailing interpretation that the local companies analysed in this paper are classified as commercial companies whose the key purpose is to perform public utility tasks at a local level (this is originally named in the French doctrine as services publics locaux) (Serrand, 2012: 279).

The field of activity of local companies in France was closely linked with the need to optimize income and expenditure in the context of the broadly understood social interest; that is why from the very beginning it was very frequently connected with the construction industry. However, when it comes to that sector, of considerable importance - apart from the construction of road infrastructure - has always been construction for social purposes. Another crucial field of activity of the companies discussed were various undertakings related to the implementation of public services of industrial or commercial nature (fr. Services publics à caractère industriel ou commercial). What is also noteworthy is the fact that the extent of operations of local companies was considerably affected by the case law of French administrative courts. It is precisely in the legislation for the first time - either through wider interpretation of social interest (Conseil d'Etat Court: CE, 10.10. 1994) or through enabling public intervention in certain new areas of expertise (Conseil d'Etat Court: CE, 23.12.1994) - where the extent of activities of so-called local companies was indirectly and gradually extended. This increase was done in laws and regulations subsequently, so to speak, as a kind of acknowledgment of the already established judicial doctrine. And so, for instance, in 2004 (Act no. 2004806 on public health policy) a decision about local companies approved in the 1990s was formally regulated; according to the decision, a local company may be used to manage or construct local civil airports, hospitals and medical centers, docks or in renovating properties registered by the relevant minister as monuments. In 2004 (Act no. 2004-669 on electronic communications and audiovisual communication services) municipalities and communes were also enabled to implement, through local commercial companies, investments related to developing terrestrial digital television as well as to increase the availability of wireless Internet network in a given territorial unit. 
It should be highlighted that despite its special status, local companies were subject to the standard competition rules and regulations for a very long time. The foregoing is also reflected in the French Commercial Code where the minimum share capital of a local company is EUR 37,000-225,000, depending on its activities ${ }^{6}$. One should bear in mind that the highest minimum share capital is reserved for local companies which operate in the broadly understood construction and infrastructure investment sectors. The fundamental difference between local companies and "classic" commercial companies is the fact that local companies should be formed by particular territorial unit and groups of territorial unit in such a way so that their combined share exceeds half the share capital of the company, the share which controls more than half the votes in its governing bodies. Obviously, the principles of operation of the governing bodies of the company are regulated by reference to the general provisions of the Commercial Code regarding public companies.

Thus, the structure of a local company helps to optimize public income and expenditure through establishing special purpose vehicles whose purpose is to implement certain investments in the social interest of a given territorial unit. In addition, that structure fosters collaboration among territorial units - since a local company has to consist of at least seven shareholders - as it allows a few neighboring municipalities and/or communes which all want to implement a specific investment to form companies to that end. In its basic form, however, a local company has a disadvantage that often enough hinders the performance of tasks in the social interest of a given territorial unit). Namely, in accordance with the EU legislation, public contract award procedure requirements should always apply to such local companies (ECJ: C-26/03). With regard to the foregoing, in French law, there are also legal means allowing public utility tasks to be performed by the territorial unit which is not restricted in terms of either public contract award procedure requirements or free competition.

\section{Local Companies Not Operating on Market Conditions}

In order to ensure the fulfillment of certain local needs that are a part of social interest, without the need to follow the principles of free-market competition and public contract award procedure, the French legislator has developed several legal forms through which local government units may realize the above needs.

The oldest legal forms, also developed by the case-law mentioned in this paper, are related to certain entities governed by public law, taking the form of either a public entity (fr. établissement public) or a public company (fr. entreprise public) 
(Wojtyczek, Machowska, 2003: 101). These entities, in the light of French doctrine, have two essential characteristics (Rivero, Waline, 2006: 38). First of all, they should represent certain protected public interests, and the nature of those interests should not be reduced to individual interests. Very often these interests are related to the needs of a given community, which is separated administratively by the division of the territory into local self-government units. Secondly, the objectives set out for the above-mentioned entities governed by public law should not be profit-oriented, and should not make from the profitability the main reason for their creation (Dupuis, Guedon, 1993: 14).

Public entity (fr. établissement public) is, therefore, a term referring to a legal person governed by public law whose activities are financed by public funds to carry out missions in the broader public interest either at the central level or at the local level (Braibant, Stirn, 2005: 127). The particular example of these public entities are the so-called public companies (fr. entreprise public), which are legal entities of private law, still financed by public funds. Sometimes, in the context of comparative law, a slightly different division can be found, where that enterprises publics, can fully operate on commercial conditions, while établissements publics cannot (Byjoch, Klimek, 2015: 12). It is undisputed, however, that these units have far reached financial autonomy and considerable administrative autonomy. Areas of their actions often involve social services (like hospitals or agencies like Agence française de sécurité sanitaire), education (universities, higher schools), or culture (museums), or other industrial and commercial spheres. In the French doctrine, there are also specific types of institutions described above: public administrative establishments (EPAs) and public industry and trade establishments (EPIC). The main difference between the above-mentioned forms of public entities is that public administrative establishments (EPAs) employ public employees, while EPIC companies generally employ private-law employees on the basis of the Labor Code (Serrand, 2012: 334-335).

The above distinction between public legal entities is often assessed as insufficient (Longchamps, 2001: 49). The gradual interpenetration of public law and private law has forced the French legislator to introduce a new, more flexible form of local company unit in the year 2006 (fr. société publique locale). The company, which was supposed to merge the advantages of public entities with private entities, while excluding it from the principle of free competition, was one again based on the construction of a joint stock company. The above-mentioned solution was supposed to affect not only the way of carrying out tasks related to the social interest of the community, but also facilitate the management and optimization of local finances in this area. It is worth to underline that the new local companies are not, in principle, subject to the rules of free competition in the market, being at the same 
time beneficiaries of the public aid from the State (Brameret, 2013: 31-32). These companies are understood as entities over which local government units have control similar to that exercised against their own internal organizational units, as they perform in principle the overwhelming part of their activity in favor of these local entities.

New local companies are lex specialis in relation to the classic joint stock company described in the French Commercial Code. This is reflected, for example, in the minimum requirement for a number of entities necessary to establish such a company, which has been reduced from seven to just two. Another limitation is that only local government units or the grouping of such entities (originally described as groupements de collectivités) may be entities that have the status of the company's shareholders.

The scope of activity of new local companies was gradually extended by the legislature, very often inspired by the case law of the already mentioned court - Conseil d'Etat. As an example after the last amendment of the law, from 2010 (Act no. 2010-559), new local companies can carry out activities related to all kinds of legal analysis of a given investment, feasibility studies, projects related to local infrastructure, acquisition and sale of real estate properties, construction or renovation works.

To sum up, the evolution of French legislation has led to a large range of legal and organizational forms available to local government units seeking to satisfy important social interests within a given territorial unit. Apart from traditional forms of public law entities, there are also some local companies in which local government units either hold majority control or are holders of the entire share capital. Local companies are an exception to the general rule relating to public limited companies (Art. L.225-1 of the Commercial Code), as they do not have to be established and function like classic private equity companies. The scope of activity of these companies has also been gradually increased by the legislator (Daucé, 2011: 9-10). The general rule, however, is that local government units can only create local companies only to perform their own tasks, without the possibility to create such companies to perform ancillary activities in the form of human resources management or optimization of a unit's budget. Indirectly, through the creation of such local companies, the French municipalities have the opportunity to optimize their income and expenditure in the broadly understood social interest. This phenomenon has been noticed by representatives of French administrative and financial law and may result in the future in various research in this field, which may be extremely valuable for the development of local finances in Poland and other Central and Eastern European countries. 


\section{Conclusions}

The public and social interest described in this paper were used by the French lawmakers to justify the introduction of new legal means for French territorial units to perform their tasks. The development of such legal means, from public law entities through local companies structured similarly to public companies, shows that along with the evolution of the concept of social interest there also evolved legal means to act in it.

The creation of the category of local companies in its original and new forms allowed the French lawmakers to completely transpose the EU regulations and the ECJ legislation regarding the interpretation of public contract award procedure directives and laws into French law. The flexibility of various forms of local public companies and their possibility of transforming from one form into another allowed territorial units to increase the number of instruments for local public income and expenditure optimization. Those instruments make it possible not only to efficiently and legally exclude the provisions of law pertaining to market competition requirements but also to choose the right legal means for a given investment or for a given case of the social interest. It has to be emphasized that the social interest discussed in the framework of French law, only with reference to Polish legislation, not only contributed to the introduction of special legal regulations but also constituted one of the reasons for their further development, allowing for better optimization of public income and expenditure. The analysis of the aforementioned processes and regulations may give rise to reflections on the content of Polish legislation on the subject, but it may also provide an impulse for further, more detailed research.

\section{References}

Brameret, S.: La société publique locale, société d'économie mixte locale à capitaux intégralement publics (The local public company, a local semi-public company with fully public capital), Contrats publics CP (Public Contracts) no. 4 (2013).

Broch, J.: L'utilité publique dans l'ancienne France (The public utility in the old France), Cahiers poitevins d'histoire du droit (Poitevin Cahiers of Law History) no. 5 (2014).

Braibant, G., Stirn, B.: Le droit administratif français (French administrative law), Paris: Dalloz, 2005.

Byjoch, K., Klimek, D.: Spółka komunalna. Aspekty prawne, ekonomiczne i społeczne (Municipal company. Legal, economic and social aspects), Toruń: Adam Marszałek, 2015.

Cornu, G. (ed.): Vocabulaire juridique (Legal vocabulary), Paris: PUF, 2005.

Chapus, R.: Droit administratif général (General administrative law), Paris: Montchrestien, 1998. 
Daucé, S.: Les SPL et les compétences locales à l'issue de la loi de réforme des collectivités territoriales (SPL and local competences after the law introducing the reform of local authorities), Les entreprises publiques locales, Actes territoriaux (Local Public Enterprises, Territorial Acts), 2011.

Donier, V.: Droit des collectivités territoriales (Law of local authorities), Paris: Dalloz, 2014.

Dupuis, G., Guedon, M.: Droit administratif (Administrative law), Paris: Armand Colin, 1993.

Lasserre, B.: Un nouveau nom et avec un trait d'union (A new name and a part of union), Sud Ouest (South West) no. 6 (2016).

Longchamps, F.: Współczesne kierunki w nauce prawa administracyjnego na zachodzie Europy (Modern directions in the study of administrative law in western Europe), Wrocław: Kolonia Limited, 2001.

Michalak, D., Fitas, A.: Partnerstwo publiczno-prywatne w modelu koncesyjnym. Wybrane zagadnienia praktyczne (Public-private partnership in the concession model. Selected practical issues), Warszawa: Wolters Kluwer, 2014.

Monjal, P.-Y.: La communautarisation de l'organisation décentralisée en France (The communitarization of the decentralized organization in France), in: Journées juridiques franco-polonaises (French-Polish legal meetings), Paris: Mare et Martin, 2013.

Orcier, P.: Régions à la découpe (Regions for cutting), Neuilly-sur-Seine: Atlande, 2015.

Rivero, J.: Waline J., Droit administratif (Administrative law), Paris: Dalloz, 2006.

Serrand, P.: Manuel d'institutions administratives francaises (Manual of French administrative institutions), Paris: PUF, 2012.

Wojtyczek, K., Machowska, A. (eds.): Prawo francuskie (French Law), Kraków: Zakamycze, 2003.

FR: Act of 2 March 1982 on Freedoms and Liberties of Municipalities, Communes, Departments, and Regions, as amended.

FR: Act no. 83-597 on local mixed economy companies.

FR: Act no. 2004-806 on public health policy.

FR: Act no. 2004-669 on electronic communications and audiovisual communication services.

FR: Act no. 2010-559 related to the new local companies

ECJ: no. C-26/03.

FR: Conseil d'Etat Court: CE Ass. 5.05.1976.

FR: Conseil d'Etat Court: CE Ass. 28.05.1971.

FR: Conseil d'Etat Court: CE, 10.10. 1994.

FR: Conseil d'Etat Court: CE, 23.12.1994. 
PL: Supreme Administrative Court: II FSK 71/13.

PL: Supreme Administrative Court: II FSK 4126/14.

PL: Supreme Court: III ARN 33/93. 